\title{
A comparison between English demonstratives and Vietnamese demonstratives in argumentative essays
}

\author{
Nguyet Minh Nguyen \\ Faculty of English Language Teacher Education, University of Languages and International Studies, Vietnam \\ National University, Hanoi. Pham Van Dong Street, Cau Giay District, Hanoi, Vietnam.
}

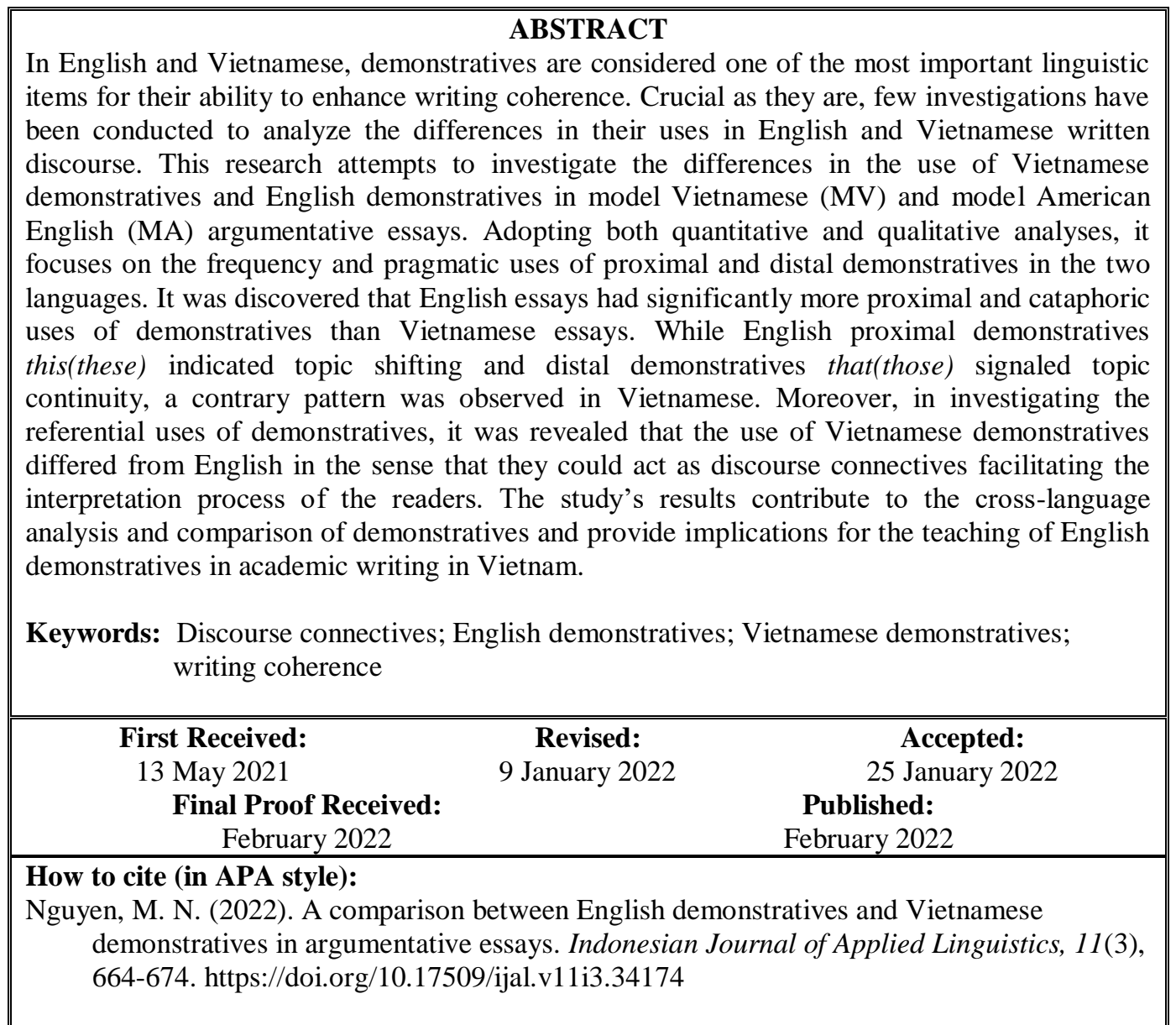

\section{INTRODUCTION}

It has been widely agreed among scholars and researchers that demonstratives are of great significance to text reference, thus enhancing text cohesion in written discourse (Celce-Murcia \& Larsen-Freeman, 1999; Halliday \& Hasan, 1976). However, similar to other groups of EFL learners, Vietnamese students have been found to share some problems in using demonstratives properly in writing English argumentative essays (Nguyen \& Lee, 2020). Therefore, it is worth questioning whether these problems are related to language transfer, or L1 interference; in other words, whether Vietnamese EFL learners are affected by the way demonstratives in their native language function in written discourse. A cross-language comparison of the use of demonstratives in both English and Vietnamese is expected to shed light on this matter.

The study of demonstratives, one important linguistic category of referring expressions, has been attracting the attention of many scholars and researchers from various backgrounds. From a

\footnotetext{
* Corresponding Author

Email: nguyetminh@vnu.edu.vn
} 
philosophical viewpoint, demonstratives could be considered a domain of indexicality indicating the connection between language and the world (Kaplan, 1989, as cited in Wolter, 2009, p. 452; whereas in linguistics, they were identified as spatial deixis, serving as a device to locate other subjects to the deictic center (Diessel, 1999). It was also emphasized that demonstratives played a fundamental part in social interaction (Diessel \& Conventry, 2020). Apart from such universal uses shared by most languages, demonstratives were found to have other uses across different languages; for example, as a hesitation signal in Korean, Japanese, and Mandarin (Diessel, 1999).

\section{Studies of English Demonstratives}

English demonstratives were traditionally discussed within the notion of proximity, in which the proximal this(these) referred to something near the speaker while the distal demonstrative that(those) was used when the referent was far from the speaker (Halliday \& Hasan, 1976). The near-distant polarity conveyed in the choice of proximal and distal demonstratives could be spatial, temporal, psychological, or sequential, as illustrated in examples (1) to (4) compiled by Celce-Murcia and Larsen-Freeman (1999).

(1) I like this car better than that one over there. [spatial]

(2) I like this movie better than that concert last night. [temporal]

(3) I like this candidate, which is why I didn't vote for that one. [psychological]

(4) This dress is less attractive than that one. [sequential]

Proximal demonstrative this goes with referents that are physically near the speaker, at present, more preferred and first mentioned; while distal demonstrative that indicates referents that are spatially far from the speaker, in the past, less preferred and second mentioned in discourse.

Since the notion of distance distinction in languages was regarded as a basic semantic feature of spatial deixis, from which "a variety of metaphorical extensions into other domains" could be represented (Anderson \& Keenan, 1985, p. 278), rather than just indicating place, demonstratives could be utilized to carry a wider range of information, through four basic uses: exophoric (situational), anaphoric (tracking the nominal referent), discourse deictic (referring to a proposition in the preceding text) and recognitional (emotional) (Diessel, 1999).

However, this distinction could not account for various uses of this and that in discourse, which led to other alternative approaches, such as the idea of "focus" and speaker's attention as the deictic center (McCarthy, 1994; Sidner, 1983; Strauss, 2002). According to this viewpoint, this is used for the current focus, signaling a shift from the old to the present topic while that is a marker of middle focus, in which little new information is needed and the focus of attention is maintained for the old topic. This framework was later supported by analyses of different corpus data (Oh, 2001). Accumulated studies on both constructed examples and spoken as well as written discourse data have contributed to the study of demonstratives and their semantic, pragmatic and discourse functions.

\section{Studies of Vietnamese Demonstratives}

A few decades ago, the study of Vietnamese demonstratives (chì dịnh tì in Vietnamese) was generally constrained to the syntactic field with analyses of examples derived from classical poetry (Nguyen, 1992). He suggested classifying Vietnamese demonstratives into three categories in accordance with their degree of distance: proximal đây(này), medial đấy(đó), ấy and distal kia; and implied that this distinction also had some relevance with the demonstratives' morphological features. However, this approach was revisited and refuted by Bui (2014) with a more comprehensive analysis of examples from various sources of written discourse (journals, poetry, conversations recorded in books). She argued that it was not appropriate to use the morphological approach to distinguish demonstratives, and there was no significant difference between the medial đấy(đó), ấy and distal demonstratives kia as Nguyen (1992) had proposed. Bui (2014) then presented a new distinction of Vietnamese demonstratives as shown in Table 1:

Table 1

Vietnamese Proximal and Distal Demonstratives (adapted from Bui, 2014)

\begin{tabular}{lll}
\hline Syntactic use & Proximal (this) & $\begin{array}{l}\text { Distal } \\
\text { (that) }\end{array}$ \\
\hline Pronominal use & đây & đấy (đó) \\
& & kia \\
Adjectival use & này & đấy/ đó \\
& & ây \\
& & kia \\
\hline
\end{tabular}

While the proximal demonstrative đây can appear in the head position and act as a pronoun, the only possible position of the other proximal demonstrative này is a determiner for nouns or noun phrases. For distal demonstratives, there are commonly four words, in which đấy and đó are interchangeable in most cases; together with kia, these three demonstratives can appear in both head and determiner position. The last distal demonstrative ấy can only occur in adjectival use raher than pronominal use.

In her study, Bui (2014) also offered accounts for the metaphoric extensions of proximal and distal demonstratives by analyzing their spatial, temporal, presentational, and discourse usage from the 
perspectives of semantics and pragmatics. Additionally, the role of demonstratives as sentencefinal particles was also discussed in Nguyen (2021), revealing that they were used to express the psychological distance between the speaker and the statement.

It is concluded that Vietnamese demonstratives can greatly contribute to other domains of linguistics with their various functions, from expressing contrastiveness, person deictic distinctions, emotional distance, temporal relations in time, to textual relations in discourse.

The complicated yet interesting uses of demonstratives in written discourse of different languages have been observed. Some comparative studies have also been conducted to analyze how English demonstratives are different from those of other languages, like Arabic (Rabadi, 2016) and Korean (Hwang \& Park, 2019). However, there have been few cross-linguistic studies between English and Vietnamese demonstratives. While the forms and discourse functions of demonstratives in each language have been extensively studied, there is yet a cross-linguistic comparison of the use of demonstratives in written discourse between the two languages.

A comparative analysis of how English demonstratives and Vietnamese demonstratives are used diversely in a certain type of written discourse may contribute to the heritage of cross-linguistic studies on demonstratives. The analysis is also expected to offer insights into the distinct uses and discourse functions of demonstratives in different languages. More importantly, it may help to explain the causes for some problems that Vietnamese EFL learners may encounter when using demonstratives in writing English argumentative essays.

In this study, the differences in the (1) frequency of demonstratives use, (2) the preference towards proximal and distal demonstratives, and (3) distinct referential uses of demonstratives in English argumentative essays and Vietnamese argumentative essays were discussed.

\section{METHOD \\ Data}

Writing samples for the study were retrieved from published reference books for training argumentative essay writing skills, including 10 essays written in Vietnamese and 10 essays written in American English, with the length varying between 600 words and 1100 words. Particularly, model American essays (MA) were randomly taken from Elements of Argument by Rottenberg and Winchell (2008), while model Vietnamese essays (MV) were selected from Tran's Model essays (2008). The topics of essays chosen were varied, ranging from computer, violent games, immigration issues, and education (sample American essays) to values of book, modesty, solidarity, and environment protection (sample Vietnamese essays), which guarantees the desirable diversity of the dataset. Moreover, these books have been commonly used as a reference material by both writing instructors and students to improve argumentative writing skills in their native language (Ho, 2011). Since the compositions are written by native expert writers and can be considered great models of the genre, the influence of proficiency interference is excluded. Comparing two sets of qualified writings is expected to reveal objective results on the differences in the uses of demonstratives in two languages.

\section{Data Analysis}

This study adopts both quantitative and qualitative research methods with an attempt to receive both conclusive statistics that establish a "relationship between or within variables" (Mackey \& Gass, 2005, p. 137) and a detailed, profound analysis of the research matter. Additionally, as mixed methods research allows writers to adopt a variety of data collection tools, the result seems to be more comprehensive (Creswell \& Clark, 2011).

First, all demonstratives employed in 20 essays were manually identified and classified into proximal and distal groups. The frequency of each category was then calculated and compared using independent samples t-test to see if there was any statistically significant difference between the two languages. Third, the tokens of two types of demonstratives were sorted according to their exophoric, anaphoric, or cataphoric uses; before the t-test was carried out again to estimate the statistical significance of the differences in frequency. Lastly, to get an insight into these uses, particular examples from the writing samples were extracted to qualitatively analyze the potential differences in the use of demonstratives between the two languages. The preference towards distal or proximal, exophoric and cataphoric reference, as well as the distinct use as discourse connectives of Vietnamese demonstratives were investigated at this stage.

\section{FINDINGS AND DISCUSSION \\ The Use of Proximal and Distal Demonstratives Overall Frequencies}

The total number of demonstratives employed in the two groups is presented in the Table 2 , in raw and normalized (per 10,000 words) frequencies.

Table 2

Overall Statistics of Demonstratives Used in 20 Essays

\begin{tabular}{lll}
\hline & MA & MV \\
\hline Total number of essays & 10 & 10 \\
Total number of words & 8203 & 8611 \\
Total number of & 71 & 55 \\
demonstratives & $(0.87 \%)$ & $(0.64 \%)$ \\
Frequency per 10,000 words & 87 & 64 \\
\hline
\end{tabular}


Although it can be inferred from Table 2 that demonstratives were generally used with a higher frequency in American English essays than Vietnamese essays; the difference was found to be statistically insignificant $(\mathrm{F}=1.47, \mathrm{Sig} .=.241)$.

However, when demonstratives were compared in the categories of proximal and distal, a different result was observed (Table 3 ).

Table 3

Comparison of Proximal and Distal Demonstratives Frequencies

\begin{tabular}{|c|c|c|c|c|}
\hline & \multicolumn{2}{|c|}{$\begin{array}{c}\text { Mean frequency } \\
\text { (per 10,000 words) } \\
(\mathrm{N}=10)\end{array}$} & \multirow[t]{2}{*}{$\mathbf{F}$} & \multirow[t]{2}{*}{ Sig. } \\
\hline & MA & MV & & \\
\hline Proximal & 47.2 & 15.43 & 4.815 & .042 \\
\hline Distal & 38.7 & 48.51 & .215 & .648 \\
\hline
\end{tabular}

While there was no significant difference in the use of distal demonstratives between the two groups, the t-test result suggested that English argumentative essays used proximal demonstratives much more frequently than Vietnamese essays $(\mathrm{F}=4.815, \mathrm{p}<0.05)$.

Interestingly, a similar pattern in the frequency of proximal demonstratives was observed when comparing English argumentative essays written by native English speakers and Vietnamese EFL learners (Nguyen \& Lee, 2020). Specifically, the use of proximal demonstratives this(these) by native English writers was statistically higher than nonnative English learners with a low level of writing proficiency, while this difference was insignificant for the high score group. In other words, the gap between native and non-native writers increased when the writing proficiency level decreased. There is a likelihood that Vietnamese EFL students with low English writing proficiency are influenced by the tendency to use less proximal demonstratives in their native language, leading to the underuse of proximal demonstratives this(these) in English argumentative essays. Learners with higher writing proficiency levels do not seem to have this problem since the effect of L1 transfer is not as considerable as low-level students. At the moment, however, this is only an assumption that requires more comprehensive investigation with larger corpora to validate.

Within groups, the different proportion between proximal and distal demonstratives in the two essay sets was also worth noticing. In English essays, the percentage of proximal demonstratives and distal demonstratives was $56 \%$ and $44 \%$ respectively, a roughly equal proportion though proximal demonstratives were a bit more frequently used. However, it was observed that the number of distal demonstratives used in Vietnamese essays tripled the number of proximal demonstratives (particularly $76 \%$ and 24\%), revealing a contradictory preference towards distal over proximal demonstratives in Vietnamese essays. This frequency disparity will be further discussed with the following qualitative analysis, which focuses on proximal and distal demonstratives' different functions in topic continuity/shifting.

\section{Different Uses in Topic Continuity/Discontinuity}

The choice of proximal and distal demonstratives in the spatial domain can be attributed to the physical position of the referent, whether it is being near or far from the speaker. Similarly, demonstratives in discourse are selected according to the characteristics and status of the referent it denotes, rather than in a random manner. This selection was recognized to depend on the values of topic continuity/ discontinuity, as suggested by Givón (1983). He proposed that differences in syntactic constructions used to express topics could signal different values of continuity; that is, a topic could be maintained or discontinued and shifted to another one, depending on different uses of syntactic features.

The qualitative analysis of the data revealed that there was a contradictory tendency in using demonstratives to mark topic continuity between English essays and Vietnamese essays. In English, proximal demonstratives this(these) indicated topic shifting while distal demonstratives that(those) maintained old focus; however, in Vietnamese, proximal demonstratives đây(này) were signals of topic continuity whereas distal demonstratives đấy(đó), kia, ấy marked topic discontinuity.

In English essays, it was found that proximal demonstratives this(these) were used to signal topic discontinuity, or a shift of focus, from what was mentioned in the preceding discourse to a new topic that was being discussed in the current text. Meanwhile, distal demonstratives took the responsibility of maintaining the old focus and continuing the topic that was previously presented. Some examples of proximal demonstratives used in English essays are presented in extracts (5) and (6).

(5) Today there are eighty-four women's colleges scattered throughout the United States, including two that are public. These colleges defend their programs as necessary to help women overcome intangible barriers in male-dominated professions. (MA1)

(6) One study found that 28 percent of Americans live in what nutritionists call "food deserts," places where big supermarkets are at least ten miles, or a twenty-minute drive, away. People who live in these places wind up buying much of their daily groceries from convenience stores or gas stations, where they can find Chef Boyardee but not baby carrots. Some communities are trying to remedy this. (MA4) 
In (5), the topic of the existence of women's colleges in the United States was switched into the argument that supported the single-sex education system, which was signaled by the use of the proximal demonstrative these. It helped connect two different themes in two sentences by denoting "women's colleges" - the only discourse item related to both sentences, functioning as the focus of the first sentence but not the second one. Likewise, these in (6) referred to the antecedent "food deserts", the topic of the previous composition, before jumping into another topic about the phenomenon that processed food was more accessible to people in the United States. This topic was then indicated not to be mentioned again by the use of this in the sentence "Some communities are trying to remedy this". The focus was now supposedly moved to the solutions to the problem of inaccessible quality food.

The use of proximal demonstratives in English essays to signal the end of one topic and indicate that the focus would be moved on to another new topic was prevalent, as further illustrated in example (7):

(7) In secondary schools, students move from one teacher to the next every 50 minutes (or 80 to 100 minutes with block periods). Five or six teachers a day; for many students, new teachers each semester. No wonder that 50 to 70 percent of students pass through their high-school years without developing a single important relationship with an adult in their school. We dump teens into industrially configured high schools, and then we complain that teens are disconnected and alienated from adults.

No Child Left Behind will not change any of this. In its single-minded focus on accountability and testing, it does not address the key issue of moving from an industrial model of school to a postindustrial model that integrates relationships and personalization with academic and personal success for every child. (MA7)

In this example, this referred to the whole preceding paragraph, whose topic was the widespread problems on loose bonding between students and teachers in the current US education system. It also indicated that the focus of the following discourse was shifted to another topic of the No Child Left Behind reform and the reasons why it could not solve the previous issues.

While proximal demonstratives this(these) were used to signal a topic shift, distal demonstratives that (those) marked topic continuity, as revealed in examples (8) to (11).

(8) In this country, the majority - obviously not everyone, but most of us - have been over-threshold in wealth and information for several generations, roughly since the end of World War II. That is a remarkable achievement; it ought to make us proud and thankful. (MA3)
(9) After school, working parents would rather their kids stay inside watching TV than play outside in unsafe streets. Those hours in front of the tube, meanwhile, feed them a diet of ads heavy on sugary cereals and greasy burgers.

(10) Turnitin stresses that they do not accuse or punish students for plagiarism - that's up to be teachers and professors. (MA9)

(11) We need, Naisbett says, to reinvent education by teaching students "how to think...to be creative." That means personalization, small schools, and relationships between students and teachers developed over several years. (MA7)

The topics in the three examples above remained the same even with the interference of such referring devices as demonstrative. In (8), the focus maintained to be the development in economy and information technology in the US, with the second sentence acted solely as an additive phrase. The topic of both sentences in (9) was children of working parents in afterschool hours, while in (10), that referred to the punishment for plagiarism - the unchanged focus of both phrases. The same pattern could be observed in (11), where that was followed by a sentence explaining what was stated in the preceding discourse.

The finding that in English argumentative essays, proximal demonstratives this(these) were used to signal topic discontinuity or focus shift; whereas distal demonstratives that(those) indicated topic continuity, or maintaining the old focus agrees with what was previously suggested by several scholars (McCarthy, 1994; Sidner, 1983; Strauss, 2002). Proposing the notion of focus, Sidner (1983) asserted that when appearing alone, this moved the focus from old to new topic whereas that kept the old focus. Similarly, Strauss (2002) described this as a marker of high focus, which required more new information for a new topic, while that required less new information and attention from the hearer, thus normally maintaining the old focus.

A completely contradictory pattern of demonstrative use could be recognized in Vietnamese essays when proximal demonstratives đây(này) tended to mark topic continuity and distal demonstratives đấy(đó), kia, ấy tended to signal topic discontinuity, which is similar to what was suggested by Bui (2014). She examined all instances of anaphoric demonstratives from various written discourse materials and concluded that while proximal demonstrative này expressed more important topics which were likely to be discussed again in the following discourse, distal demonstrative $\hat{a} y$ indicated less important topics which were not likely to appear again. The same pattern could be observed in 10 model Vietnamese argumentative essays in this study. Examples of proximal demonstratives marking topics that were 
more important and continued to persist longer in the discourse are presented in extract (12)..

(12) Câu tuc ngĩ trên đây
sentence proverb above $\mathrm{D}$

$\begin{array}{llll}\text { vùa } & \text { là quan niệm dúng đắn của } \\ \text { CONJ } & \text { is perception right of }\end{array}$

nhân dân ta về cốnghiến và

our people about devotion and

hường thụ, vì̀a là lời cảnh cáo phê phán

enjoyment, CONJ is warning criticize

nhũng kẻ bóc lột, ăn bám. [....] Ý nghĩa

exploiters, sponger Meaning

đủng đắn và tích cực của quan niệm

right and positive of perception

này hoàn toàn phù hợp với

DEM.PRO completely suitable with

nguyên tắc phân phối trong xã hội ta

principle distribution in our society ngày nay:

làm nhiều hưởng nhiều, làm

nowadays: work much earn much, work

it hưởng ít, không làm không hưởng

little earn litte, no work no earn

This proverb above expresses both our people's right perception about devoting and enjoying and a warning against exploiters and spongers [....] The right and positive meaning of this perception is completely consistent with the principle of distribution in our society today: if you work much, you can earn much; if you work less, you enjoy less; if you do not work, you cannot earn anything. (MV5)

In example (12), proximal demonstratives đây and này were both used to refer to a single perception, the shared viewpoint between Vietnamese people about equality in society. This was the main focus of the whole essay; thus, it was repeatedly mentioned to maintain the topic. Proximal demonstratives marked its great importance and showed that this topic would remain longer in the discourse. Similarly, in example (13), này and đây denoted the same issue, the value of modesty:

(13) Bàn về vấn đề này,

Discuss about issue DEM.PRO

Lâm Ngũ Đưòng, một họ giả đã

PROPER NAME, a/one scholar PAST

viết: Lòng khiêm tốn có thể coi là

write: Modesty probably look is

môt bản tính căn bản cho con người

a/one nature basic for humans

trong nghệ thuạt xủ thế và

in art behaviors and

đối đãi vói sụv vật. Đây là

treatment with things. DEM.PRO is

một nhận xét chí li, một

a/one comment reasonable, a/one

lời khuyên thiết thực cho mọi ngườ,

advice practical for everyone,

nhất là tuổi trẻ. (MV10)

first is youth.

Discussing this issue, Lin Yutang, a Chinese scholar wrote: Modesty can be considered a fundamental human virtue in the art of treating and dealing with things. This is a wise saying, a piece of practical advice for everyone, especially young people.

With the use of proximal demonstratives, the writer attempted to give further explanation on the topic of modesty, without any potential shift of focus. The indication of that important topic helped the writer to orient the readers' attention towards following discourse, where other discussions on the topic of modesty could be found.

While proximal demonstratives đây(này) helped maintain the topic continuity, distal demonstratives đấy(đó), kia, ấy in Vietnamese argumentative essays were likely to mark topic discontinuity, or focus shift.

(14) Chặt cây lấy gố, mở mang diện tích

Cut tree take wood, expand area

trồng trọt, canh tác; đốt nưong làm

planting, cultivation; burn hills make

rẫy, săn bắn thú quý... nhũng

fields, hunting rare animals... PLURAL

viẹc làm đó kéo dài trong nhiều

activities DEM.DIS last in many

năm sẽ làm cho diện tích rùng

years FUTURE make area forest

tụ nhiên ngày càng thu hẹp lại,

nature more and more narrow,

ảnh hưởng nghiêm trọng đến

affect serious to

sụ cân bằng sinh thái. (MV1)

balance ecology

Cutting down trees for timber, expanding the cultivation area, slash-and-burn agriculture, hunting animals... those activities lasting for many years will cause the natural forest area to shrink, seriously affecting the ecological balance. (MV1)

In example (14), from the point that was marked by the distal demonstrative đó, the topic of activities that harmed the environment did not appear again in the following discourse; instead, a new topic on negative consequences of these activities was expected to be presented. Rather than the same topic, what was expressed after distal demonstratives was just associated information forming another topic.

(15) Thưc tế cho thấy Hồ

Reality show PROPER N

Chủ tịch là một lãnh tụ Cách mạng

President is a/one leader revolution

vĩ đại, môt bậc hiền triết, một

great, a/one philosopher, a/one

nhà văn hóa lớn của dân tộc

cultural activist great of peoples

và nhân loại. Tất cả nhũng điều

and mankind. All PLURAL thing

ấy kết tinh trong một

DEM.DIS crystalize in a/one

con người rất mục giản dị và khiêm tốn.

human very simple and humble.

The fact is that President Ho was a great revolutionary leader, philosopher, and cultural activist of our people and mankind. All of those 
things were included in a perfectly simple and humble being. (MA10)

In example (15), the distal demonstrative ấy referred to all the great titles that President Ho achieved, which also marked the end of that topic and the shift of focus to another topic of President's modesty. From this point forward, readers were not likely to read about President Ho's great achievements anymore, but a new topic of his modesty would become evident in the following discourse.

To conclude, the disparity in the choice of proximal and distal demonstratives indicated the difference in topic continuity/ discontinuity function in the written discourse of the two languages. While in English proximal demonstratives this(these) signaled topic shifting and distal demonstratives that(those) maintained old focus, a contrast case was observed in Vietnamese. Proximal demonstratives đây(này) were indicators of topic continuity, whereas distal demonstratives đấy(đó), kia, ấy were used to mark topic discontinuity.

This finding can somehow account for the previous observation that distal demonstratives were much more frequently used in Vietnamese than in English. In argumentative essays, the practice of moving from one point to another argument is commonly seen, and one of the devices frequently used is demonstratives. Since in English proximal demonstratives are responsible for topic shifting, English writers tend to utilize this function to connect the preceding points to the next ones. However, in Vietnamese, distal demonstratives signal topic shifting, or a change in focus; therefore, they may be more preferred than proximal demonstratives in linking ideas in argumentative essays.

\section{Referential Uses of Demonstratives}

\section{Exophoric, Anaphoric, and Cataphoric Uses}

When comparing across groups, the exophoric and anaphoric uses of demonstratives showed almost no significant difference between the two groups (Table 4); however, a critically higher frequency of cataphoric uses was observed in the English essay group $(\mathrm{F}=15.296, \mathrm{p}<0.001)$. In fact, there was no cataphoric use of demonstratives found in Vietnamese essays; whereas English essays had 12 cases in total.

Table 4

Comparison of Exophoric, Anaphoric, and Cataphoric Frequencies

\begin{tabular}{lcccc}
\hline & \multicolumn{2}{l}{$\begin{array}{l}\text { Mean frequency (per } \\
\mathbf{1 0 , 0 0 0} \text { words) }(\mathbf{N = 1 0})\end{array}$} & F & Sig. \\
\cline { 2 - 3 } & $\mathbf{M A}$ & $\mathbf{M V}$ & & \\
\cline { 2 - 4 } Exophoric & 7.59 & 10.53 & 2.524 & .130 \\
Anaphoric & 65.32 & 53.41 & .926 & .349 \\
Cataphoric & 13.00 & 0.00 & 15.296 & .001 \\
\hline
\end{tabular}

The proportions between the three uses of proximal and distal demonstratives in the two essay groups are presented in Figure 1. Both groups showed a very high percentage of anaphoric use, indicating that demonstratives were most commonly used to refer anaphorically in discourse. However, the result also revealed interesting dissimilarity between proximal and distal demonstratives in exophoric uses, which will be further discussed in the following part.

\section{Figure 1}

The Proportion of Three Uses in Proximal and Distal Demonstratives

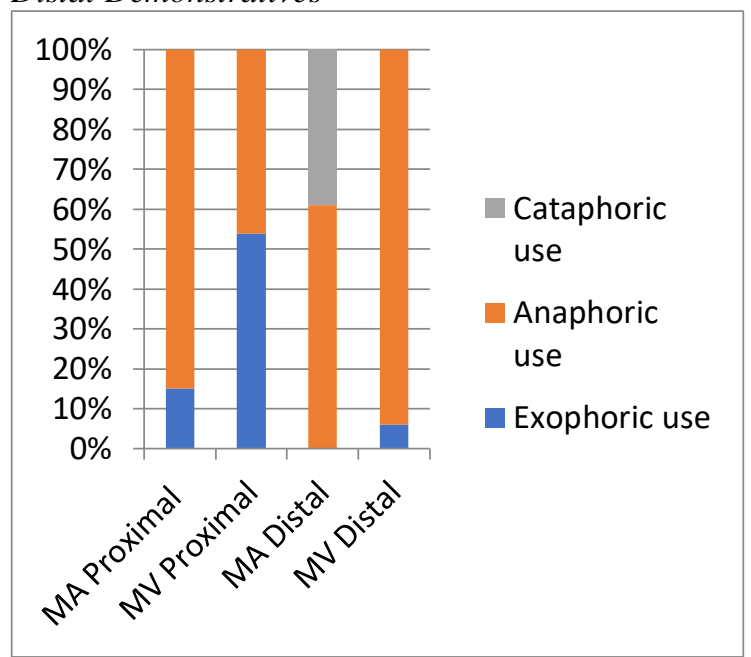

In Vietnamese essays, both distal and proximal demonstratives were used to denote physical referents which did not have antecedents in discourse, with a remarkable percentage $(54 \%)$ of proximal demonstratives đây(này). In contrast, no English distal demonstratives that(those) used exophorically were found; and only 6 out of 40 , accounting for $15 \%$ of English proximal demonstratives this(these) were observed to make exophoric reference.

In six cases of exophoric uses of English proximal demonstratives, this had such temporal referents as "this century" (MA3), "this week" (MA6), "this fall" (MA9), or "this day" (MA10). The first referent could be easily identified by the readers, since "century" indicated a long period, even longer than a person's lifetime, so the term "this century" absolutely referred to the 21 st century all of us are living in; however, the latter three expressions were highly dependent on the context, particularly the time when essays were written. Other exophoric uses in English essays included "this country" (MA8) and "this column" (MA9), from which their referents could also be found even without any specification.

(16) But what about the millions of unskilled laborers who arrive in this country every year? (MA8) 
(17) Computers and the Internet have certainly revolutionized writing in general and research in particular. To get the fact for just this column, for instance, I checked dozens of websites, downloaded new stories, and read Turnitin's own promotional literature - right here in my den. (MA9)

In Vietnamese essays, apart from one case of exophoric use that had spatial referent: "cuộc đờ $i$ này" (MV10), which could be translated into "this life", all other cases were temporal adverbial expressions defining deictic time. Since the deictic center was defined as the present, proximal demonstratives đây also indicated the present, while distal demonstratives (in this study's sample, only kia was identified) signaled the past.

To perform a temporal reference function, Vietnamese proximal demonstrative đây normally combined with lexical terms indicating proximity in the past direction. For example, to express a very short time right before utterance time, đây went with adjectives of nearness like gần ('near'), which formed the temporal adverbial expression gần đây ('recently') (Example 18). Other cases involved the use of truoóc đây ('front/ahead' + proximal demonstrative đây $\square$ 'in the past'), a temporal adverbial denoted a time span which was placed in front of the deictic center (as in example 19)
(18) Nhũng năm gần đây
PLURAL year near DEM.PRO
vòng tay nhân ái của cộng đồng....
arms loving of community.... (MV2)
(19) Nông thôn trước đây
Rural areas front DEM.PRO
thuoòng được coi là không gian
often PASSIVE look is space
trong lành... (MV1)

In recent years, loving arms of the community.... fresh

In the past, rural areas were considered fresh spaces....

With regards to distal demonstrative kia, it was used to indicate a further time back in the past, not near to present, as illustrated in example (20). The noun " $x u a$ " ('ancient time') was combined with kia to refer to a very old time before the present.

(20) Trong xã hội phong kiến xua

$$
\text { In society feudality ancient }
$$

kia, phần lón của cải do

DEM.DIS, majority goods because

người lao động làm ra.... (MV5)

human labor make

In the old feudal society, most of the goods were made by laborers.

One interesting observation about the exophoric uses of Vietnamese demonstratives in this study's writing samples was that no matter what type of demonstrative was used, proximal or distal, the temporal referents denoted by the demonstratives were easily identified, unlike some temporal deictic expressions formed by proximal demonstratives in English argumentative writings in this study, which required more information about the context to detect their exophoric referents.

Vietnamese Distal Demonstratives đó as
Discourse Connectives
One distinct referential use of Vietnamese
demonstratives observed in this study's writing
samples was the involvement of distal
demonstrative đó in constructing different discourse
connectives, which can be summarized and
displayed in Table 5.

Table 5

Discourse Connectives Marked by Demonstrative đó

\begin{tabular}{llll}
\hline Demonstrative & Discourse connectives & Meaning & Function \\
\hline đó & trong khi đó & 'whereas' (lit. in-time-that) & adversive \\
& do đó & 'therefore' (lit. because-that) & causal \\
& tù đó & 'thus' (lit. from-that) & \\
& sau đó & 'then' (lit. after-that) & temporal \\
\hline
\end{tabular}

In these cases, the information that the demonstrative referred to in the preceding text could be considered the source of semantic relations marked by these connectives (Bui, 2014). Take excerpt (21) as an example, the linking phrase tù đó ('thus') indicated a causal relation, in which the subsequent information (having the spirit of selfcontrol, self-confidence, and creativity) was the consequence of the previously mentioned one (the ability of self-assessment).
(21) Đồng thò̀i
mối cá nhân
At the same time each individual
se tụ đánh giá được
FUTURE self assess obtain

năng lực bản thân, tù̀ đó capacity self, from DEM.DIS có tinh thần tư chủ, tụ tin have spirit self-control self-confidence sáng tạo trong lao động. (MV5) creativity in labor

At the same time, each individual will be able to self-assess his or her own capacity, thus having the spirit of self-control, selfconfidence, and creativity in labor.

Furthermore, the demonstrative đó could also be used to form aversive conjunction, as illustrated in example (22). The situation stated in the first 
sentence, denoted by the distal demonstrative đó was put in contradiction with the situation presented in the second sentence; in other words, a contrasting relation was indicated with the connective trong khi đó.

\section{(22) Người làm ra của cải vật chất lại Human make goods material again phải sống nghèo khổ, thiếu thốn. have to live poor lack Trong khi đó, kẻ không làm In time DEM.DIS, human no work thì lại được hương thu rất nhiều. CONJ again obtain enjoy a lot.}

The people who make material wealth have to live in poverty and deprivation. Meanwhile, those who do not work can receive a lot. (MA5)

Last but not least, distal demonstrative đó also formed temporal connectives, like sau đó ('after that') in example (23). The distal demonstrative đó here referred to "feeding themselves", a preceding action before "contributing to the community" - the following action which was presented in the second sentence.

(23) Con người phải làm việc, trước hết

$$
\text { People have to work first }
$$

là để nuôi sống bản thân, sau

is to feed self after

đó là góp phần xâydụng

DEM.DIS is contribute build

cuộc sống chung của cả cộng đồng.

life common of all community.

People have to work, first to feed themselves, then contribute to build up the common life of the community. (MV5)

It is observed in the sample's data that the distal demonstratives provide both explicit connectives and anaphoric referents as hints for readers to interpret the relationship between propositions in discourse. As Bui (2014) pointed out, it does not only have a referring-tracking function, but also contributes to the interpretation process of readers.

This distinct function of Vietnamese distal demonstratives may also explain its higher proportion over proximal demonstratives in Vietnamese argumentative essays. Since distal demonstrative đó can constitute common linking phrases in Vietnamese, they are used more frequently than proximal demonstratives.

\section{CONCLUSION}

With the data of 20 compositions, the study attempted to investigate the differences in the use of Vietnamese demonstratives in comparison with English demonstratives in Vietnamese and English argumentative essays. Quantitative and qualitative analyses were both conducted to generate objective and insightful results in the comparison of the two languages.

First, regarding the use of proximal and distal demonstratives, the quantitative test discovered that English proximal demonstratives this(these) enjoyed a significantly higher frequency than Vietnamese proximal demonstratives đây(này) in argumentative essay discourse. This is assumed to be the contributing factor for the underuse of this(these) in English argumentative essays written by Vietnamese EFL learners with a low level of writing English, since they may be affected by the interference of their native language.

Moreover, the preference towards proximal and distal demonstratives shown in two languages contradicted each other. While English writers utilized both types of demonstratives, and proximal demonstratives this(these) were used a bit more frequently than distal demonstratives that(those), Vietnamese essays showed a clear preference towards distal demonstratives đấy(đó), kia, ấy with much higher frequency than proximal demonstratives đây(này). Second, the function of proximal and distal demonstratives in topic continuity was also different between English and Vietnamese essays, as revealed by the qualitative analysis. In English, proximal demonstratives this(these) were indicators of topic shifting and distal demonstratives that(those) maintained old focus; whereas Vietnamese proximal demonstratives đây(này) signaled topic continuity and distal demonstratives đấy(đó), kia, ấy were used to mark topic discontinuity.

In terms of referential uses, anaphora was the most frequent use of demonstratives in both languages. Cases of cataphoric demonstratives in English argumentative essays were common, whereas no single cataphoric use of Vietnamese demonstratives was found in the study. Regarding exophoric use, only English proximal demonstratives this(these) were found to be used while both types of Vietnamese demonstratives contributed to denote both temporal and spatial referents out of discourse context.

In analyzing another use of Vietnamese demonstratives, it was found that the distal demonstrative đó facilitated the interpretation process of the readers by both referring to the antecedents and acting as discourse connectives presenting the relationship between what was stated in the preceding text and what was followed in discourse.

The study's findings provide a source of reference for researchers who are interested in the study of demonstratives in different languages. Indeed, when putting English demonstratives in comparison with demonstratives of other languages, both similarities and differences in their uses and functions in written discourse can be discovered, 
which opens more room for linguistic researchers to investigate.

More notably, the study's results can also account for the problem that Vietnamese EFL learners face in using demonstratives in writing English essays, particularly the underemployment of this(these) as a connecting device improving text coherence. Therefore, the study's discussion may be useful for teachers and learners of languages. Specifically, when introducing the uses of demonstratives in written discourse to Vietnamese EFL learners, teachers can anticipate students' difficulties caused by L1 interference and prepare appropriate materials and instructions to help nonnative students, especially low-level ones to avoid influence from their mother tongue.

The study only deals with a rather small number of data, which cannot well represent the matter, thus somehow prevents the researcher to reach a profound conclusion. More in-depth studies with larger data size should be conducted on the use of demonstratives between the two languages, especially the difference in anaphoric use, which has not been mentioned in this research.

\section{REFERENCES}

Anderson, S. R., \& Keenan, E. L. (1985). Deixis. In T. Shopen (Ed.), Language typology and syntactic description (pp. 259-308). Cambridge University Press.

Bui, T. L. (2014). Vietnamese demonstratives: A spatially-based polysemy network [Unpublished doctoral dissertation]. The University of Queensland. https://doi.org/10.14264/uq1.2014.430

Celce-Murcia, M., \& Larsen-Freeman, D. (1999). The grammar book: An ESL/EFL teacher's course (2nd ed.). Heinle and Heinle Publishers.

Creswell, J. W., \& Clark, V. L. P. (2011). Designing and conducting mixed methods research. SAGE Publications.

Diessel, H. (1999). Demonstratives: Form, function, and grammaticalization (Vol. 42). John Benjamins Publishing Company.

Diessel, H., \& Conventry, K. R. (2020). Demonstratives in spatial language and social interaction: An interdisciplinary review. Frontier Psychology, 11. https://doi.org/10.3389/fpsyg.2020.555265

Givón, T. (1983). Topic continuity in discourse: An introduction. In T. Givón (Ed.), Topic continuity in discourse: A quantitative language study (pp. 1-41). John Benjamins.

Halliday, M. A. K., \& Hasan, R. (1976). Cohesion in English. Longman.
Ho, V. (2011). Non-native argumentative writing by Vietnamese learners of English: A contrastive study [Unpublished doctoral dissertation]. Georgetown University. http://hdl.handle.net/10822/553147

Hwang, S. H., \& Park, J. U. (2019). A comparative study on demonstratives in Korean and English. The Journal of Mirae English Language and Literature, 24(2), 415-442. https://doi.org/10.46449/MJELL.2019.05.24.2 .415

Mackey, A., \& Gass, S. M. (2005). Second language research: Methodology and design. Lawrence Erlbaum Associates Publishers.

McCarthy, M. (1994). It, this, and that. In M. Coulthard (Ed.), Advances in written text analysis (pp. 266-275). Routledge.

Nguyen, N. M., \& Lee, S. G. (Eds.). (2020). English demonstratives in argumentative essays by Vietnamese EFL students and native English speakers. Proceedings of VietTESOL international convention 2020: Innovation and globalization. (pp. 213-231). Danang Publishing House.

Nguyen, P. P. (1992). Vietnamese demonstratives revisited. The Mon-Khmer Studies Journal, 20, 127-136

Nguyen, T. H. Q. (2021). Demonstratives as sentence-final particles and the architecture of the periphery in Vietnamese. VNU Journal of Foreign Studies, 37(3), 119-134. http://dx.doi.org/10.5539/ells.v6n1p16

Oh, S. (2001). A focus-based study of English demonstrative reference: With special reference to the genre of written advertisements. Journal of English Linguistics, 29(2), 124-148. https://doi.org/10.1177/00754240122005260

Rabadi, R. I. (2016). Demonstrative pronouns in English and Arabic: Are they different or similar? English Language and Literature Studies, 6(1), 16-27. http://doi.org/10.5539/ells.v6n1p16

Rottenberg, A. T., \& Winchell, D. H. (2008). Elements of argument: A text and reader $\left(9^{\text {th }}\right.$ ed). Bedford/St. Martin's.

Sidner, C. (1983). Focusing in the comprehension of definite anaphora. In M. Brady \& R. C. Berwick (Eds.), Computational models of discourse (pp. 267-330). The MIT Press.

Strauss, S. (2002). This, that and it in spoken American English: A demonstrative system of gradient focus. Language Sciences, 24(2), 131-152. https://doi.org/10.1016/S03880001(01)00012-2

Tran, T. T. (2008). Model essays ( $9^{\text {th }}$ ed). Ho Chi Minh City General Publishing House. 
Wolter, L. (2009). Demonstratives in philosophy and linguistics. Philosophy Compass, 4(3),
451-468. https://doi.org/10.1111/j.1747-

9991.2009.00205.x 